\title{
Perencanaan Sistem Long Term Evolution di Wilayah Kota Denpasar Memanfaatkan Bale Banjar untuk Menempatkan Base Station

\author{
Yoel Sthefianus ${ }^{1}$, Pande Ketut Sudiarta ${ }^{2}$, Gede Sukadarmika ${ }^{3}$ \\ ${ }^{1,2,3}$ Program Studi Teknik Elektro, Fakultas Teknik, Universitas Udayana \\ Email: yoel.sthefianus@gmail.com ${ }^{1}$, sudiarta@unud.ac.id ${ }^{2}$, sukadarmika@unud.ac.id $^{3}$
}

\begin{abstract}
ABSTRAK
Perencanaan sistem jaringan LTE dipengaruhi oleh beberapa faktor, salah satunya adalah faktor kontur wilayah yang berbeda. Kontur permukaan wilayah berpengaruh terhadap cakupan area yang dihasilkan suatu base station. Perencanaan jaringan berdasarkan analisis perhitungan, tidak mempertimbangkan kontur wilayah, maka untuk menunjang hal tersebut diperlukan simulasi menggunakan software Atoll. Metode pada penelitian ini menggunakan perhitungan dan simulasi software Atoll. Penempatan base station memanfaatkan 385 Bale Banjar sebagai titik site menara rooftop. Penempatan ini dilakukan di Bale Banjar dikarenakan mudahnya akses perijinan tempat, seperti base station pada Bale Banjar Balun. Berdasarkan hasil perhitungan dan pemodelan simulasi jarak jangkauan antena base station dengan model propagasi Cost-231 Hatta frekuensi $1800 \mathrm{MHz}$, diperoleh jarak sebesar 1,186 km. Simulasi perencanaan sistem LTE di wilayah kota Denpasar memerlukan 55 site, terdiri dari 54 site yang memanfaatkan Bale Banjar untuk menempatkan base station dan 1 site di luar kawasan Bale Banjar, serta diperlukan pengaturan electrical tilt sebanyak 40 site untuk mengatasi permasalahan cakupan area.
\end{abstract}

Kata Kunci : Bale Banjar, Coverage Area, Long Term Evolution, Software Atoll.

\section{PENDAHULUAN}

Untuk meningkatkan kualitas pelayanan telekomunikasi teknologi Long Term Evolution (LTE) adalah suatu solusi. Dalam mencapai kebutuhan tersebut penyedia layanan telekomunikasi mengembangkan perluasan dan peningkatan kapasitas jaringan dengan melakukan perencanaan jaringan telekomunikasi. Berdasarkan penelitian yang telah dilakukan yaitu melakukan perencanaan LTE dan membuat site-site menara rooftop baru yang diimplementasikan pada Bale Banjar di Kota Denpasar dengan menggunakan analisis perhitungan. Kontur ketinggian wilayah yangberbedatidak dipertimbangkan dalam penelitian-penelitian yang pernah dilakukan, sedangkan faktor tersebut sangat berpengaruh terhadap cakupan area. Pada wilayah yang memiliki kontur yang ekstrim maka coverage area yang dihasilkan semakin sempit menyesuaikan dengan kontur wilayah disekitarnya, sedangkan pada wilayah dengan kontur yang landai coverage area yang dihasilkan dapat lebih luas.[1].

Peneliian ini dikembangkan dari penelitian yang pernah dilakukan mengenai perencanangan sistem LTE menggunakan analisis perhitungan dan pemanfaatan Bale Banjar untuk penempatan base station[2]. Pengembangan yang dilakukan pada penelitian ini adalah pemodelan simulasi menggunakan software Atoll. Simulasi menggunakan software Atoll bertujuan untuk memperoleh cakupan perencanaan sel sesuai keadaan sebenarnya yang mengacu pada kontur wilayah permukaan penempatan site.

Penelitian ini memanfaatkan Bale Banjar yang ada di wilayah kota Denpasar untuk menempatkan site base station. Dengan sejumlah 385 Bale Banjar untuk mengcakupi seluruh wilayah kota Denpasar. Pemanfaatan fasilitas umum seperti Bale Banjar ini memberikan kemudahan dalam aspek perijinan tempat.

\section{TINJAUAN PUSTAKA}

\subsection{Pengenalan LTE}

The Third Generation Partnership Project (3GPP) adalah Long Term Evolution (LTE) adalah nama yang suatu proyek dalam mengembangkan standar komunikasi bergerak Universal Mobile Telecommunication System (UMTS) untuk mengatasi kebutuhan telekomunikasi. 
Berdasarkan standar LTE, kecepatan downlink hingga $100 \mathrm{Mbps}$ [3].

\subsection{Menara Rooftop pada Bale Banjar}

Simulasi penelitian ini menggunakan 385 Bale Banjar yang ada di Kota Denpasar sebagai titik penempatan site menara rooftop. Beberapa alasan penggunaan Bale Banjar sebagai penempatan menara rooftop, yaitu: 1) Bale Banjar sendiri merupakan tempat pertumbuhan dan berkembangnya kegiatan kemasyarakatan di wilayah kota Denpasar, 2) Dalam penempatan menara rooftop memerlukan biaya sewa dan pemeliharaan, alangkah baiknya jika biaya sewa tersebut jatuh kepada pihak pengelola banjar yang ada pada tempat tersebut guna memajukan perkembangan kegiatan kemasyarakatan dan juga terjadi interaksi sosial antara masyarakat dan penyedia layanan telekomunikasi.

Penggunaan menara rooftop pada Bale Banjar yang ada di kota Denpasar yang diletakan di atas Bale Banjar yaitu Bale Banjar Balun yang berada di kecamatan Denpasar Barat, Jalan Setiabudi, pada koordinat Latitude $-8.64758^{\circ}$ dan Longitude $115.20923^{0}$ dan Bale Banjar Sari Ubung, Jalan Haji Umar Sahid Cokrominoto, pada koordinat Latitude -8.63198 dan Longitude 115.20205, yang mana Bale Banjar ini terdiri dari 2 lantai, lantai dasar pada banjar ini biasanya digunakan masyarakat sekitar sebagai tempat untuk berkumpul dan bermusyawarah. Sedangkan pada lantai 2 difungsikan sebagai penempatan bale kulkul dan juga penempatan menara rooftop. Dengan ketinggian antena yang digunakan pada Bale Banjar ini, yaitu 18 meter dari permukaan tanah sesuai dengan peraturan ketinggian bangunan yang dimungkinkan untuk daerah Denpasar, untuk tinggi bangunan dengan jumlah 2 lantai[1], ditunjukan dalam Gambar 1 dan Gambar 2:

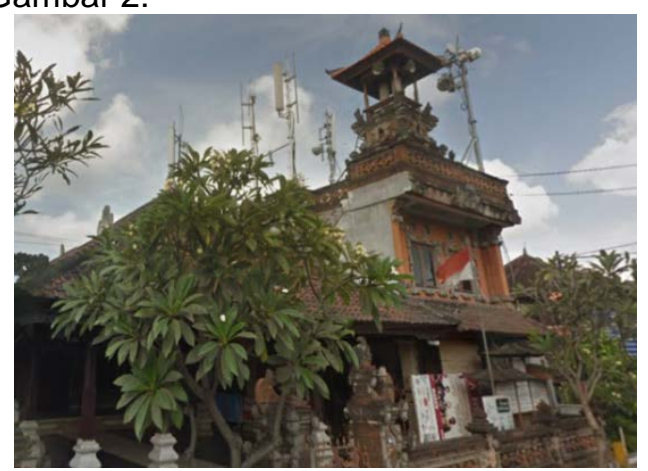

Gambar 1. Menara Rooftop pada Bale Banjar Balun

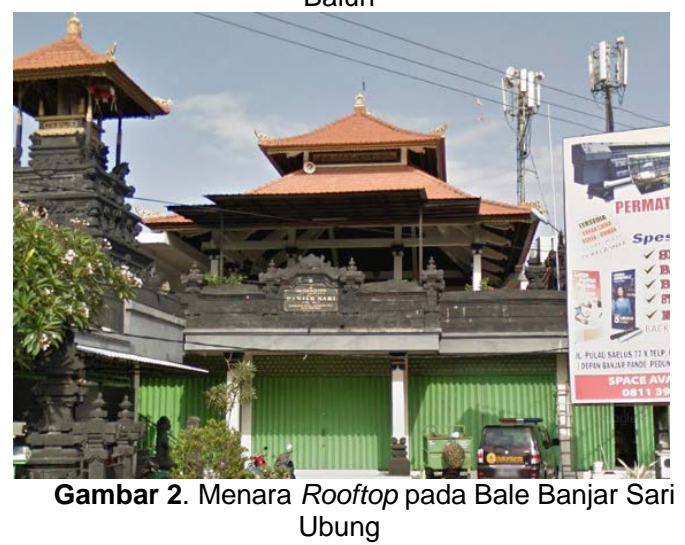

\subsection{Maximum Allowable Path Loss (MAPL)}

MAPL merupakan perhitungan nilai propagasi maksimum antara perangkat eNode $B$ dan mobile station.

Ada dua nilai perhitungan MAPL yaitu arah uplink dan downlink. Nilai uplink digunakan untuk menentukan maksimum redaman propagasi dari mobile station ke eNode $B$. Nilai downlink adalah maksimum redaman propagasi dari eNode $B$ ke mobile station untuk keperluan komunikasi user dalam cakupan suatu daerah. [1]

Ada 3 tahap untuk memperoleh nilai MAPL yaitu menghitung nilai Effective Isotropic Radiated Power (EIRP), menghitung nilai Receiver Sensitivity (RS) dan kemudian menghitung nilai MAPL.

1. Perhitungan Nilai EIRP

Menghitung nilai EIRP dapat mengacu pada (1) sebagai berikut. [4]

$E I R P=P t x+G t x-$ Loss System

dengan:

Ptx = Daya transmitter $(\mathrm{dBm})$

Gtx = Gain pada antena transmitter (dB)

Loss= Loss pada konektor transmitter (dB)

\section{Perhitungan Parameter Receiver Sensitivity \\ Menghitung nilai Receiver Sensitivity dapat mengacu pada (2) sebagai berikut.[4]}

$R S=S N R+N_{f}+N_{r}$

dengan :

SNR = Signal to Noise Ratio $(\mathrm{dB})$
$\mathrm{N}_{f}=$ Noise Figure Receiver $(\mathrm{dB})$
$\mathrm{N}_{r}=$ Thermal Noise $(\mathrm{dB})$ 
3. Perhitungan Nilai MAPL

Referensi [ menunjukan bahwa untuk menghitung nilai MAPL mengacu pada (3) sebagai berikut. [4]

$$
\begin{aligned}
M A P L= & E I R P-R S-G R_{x}+\operatorname{Loss}_{x}- \\
& \text { Fade Margin }
\end{aligned}
$$

dengan:

$$
\begin{array}{ll}
\text { EIRP } & =\text { Effective Isotropic Radiated } \\
\text { Power }(\mathrm{dBm}) & \\
\text { RS } & =\text { Receiver Sensitivity }(\mathrm{dBm}) \\
\mathrm{GR}_{x} & =\text { Gain pada antena receiver } \\
(\mathrm{dB}) & \\
\text { LossR }_{x} & =\text { Loss pada receiver }(\mathrm{dB}) \\
\text { Fade Margin } & =\text { Batas fading sinyal yang } \\
\text { diterima }(\mathrm{dB}) &
\end{array}
$$

\subsection{Propagasi Cost-231 Hatta}

Persamaan (4) digunakan untuk perhitungan rugi-rugi propagasi antenna dengan model propagasi Cost-231 Hatta.[4]

$$
\begin{gathered}
L=46,3+33,9 \log -13,82 \log h_{b}+a\left(h_{m}\right) \\
+(44,9- \\
\left.6,55 \log h_{b}\right) \log d+C_{M}
\end{gathered}
$$

$a\left(h_{m}\right)$ merupakan nilai faktor koreksi antena mobile yang dapat dihitung dengan mengacu pada (5)

$$
a\left(h_{m}\right)=3,2\left(\log 11,75 h_{m}\right)^{2}-4,97 d B
$$

dengan,

$$
\begin{aligned}
L= & \text { Path Loss rata-rata }(\mathrm{dB}) \\
f= & \text { frekuensi }(\mathrm{MHz}) \\
h_{b}= & \text { tinggi antena Base Station }(\mathrm{m}) \\
h_{m}= & \text { tinggi antena Mobile Station }(\mathrm{m}) \\
d= & \text { jarak Mobile Station dan Base } \\
& \text { Station }(\mathrm{m})
\end{aligned}
$$

\subsection{Tilting Antena}

Tilt antena adalah sudut kemiringan antenna dalam satuan derajat, posisi antena akan semakin turun jika sudutnya semakin besar [5]. Pada saat melakukan optimasi jaringan, pengaturan tilting antena yang sesuai sangat penting karena akan mempengaruhi kinerja dari sebuah BTS dan jarak cakupan layanan sinyal yang dihasilkan.

Proses tilting antena dapat dilakukan dengan 2 teknik, yaitu:

1) Mechanical Tilting: proses mengubah keadaan antena dari sisi fisik yaitu arah azimuth dan sudut kemiringan antenna. Hal ini akan memengaruhi coverage area BTS. Perubahan arah mechanical tilting memiliki 2 arah yaitu uptilt (mengubah kemiringan antena lebih ke atas) dan downtilt (mengubah kemiringan antena lebih ke bawah). Proses uptilt dan downtilt dalam proses mechanical tilting ditunjukkan dalam Gambar 3 dan Gambar 4.

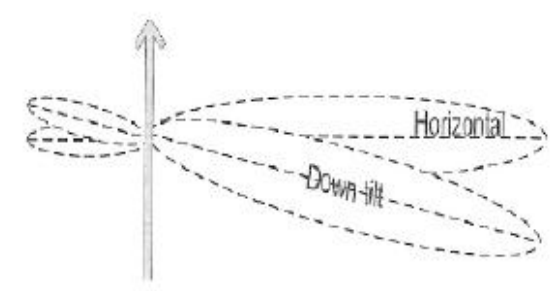

Gambar 3. Uptilt dalam Mechanical Tilting [3]

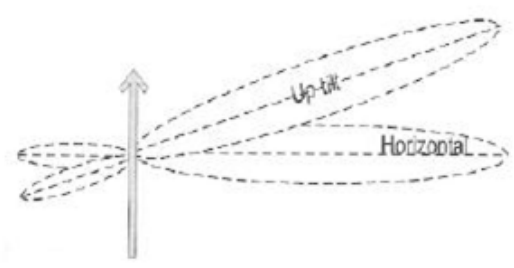

Gambar 4. Downtilt dalam Mechanical Tilting [3]

2) Electrical Tilting: proses mengubah keadaan kelistrikan (phasa) antena, sehingga terjadi perubahan pada beamwidth antenna. Proses electrical tilting ini hanya akan bedampak pada ukuran main lobe yang dipancarkan oleh antena.

\subsection{Software Radio Planning Atoll}

Atoll adalah software radio planning yang memungkinkan user/planner untuk membuat sebuah proyek perencanaan microwave ataupun perencanaan jaringan radio dengan satu set alat dan fitur yang komperhensif dan bahkan melihat prediksi coverage area sebuah site dalam satu aplikasi.

Beberapa prediksi study dari cakupan area layanan dapat dikonfigurasikan sesuai kehendak planner [6]. Study tersebut adalah sebagai berikut.

1) Perhitungan area yang ditutupi oleh level sinyal dari tiap cell disebut Coverage by signal level

2) Perhitungan area yang ditutupi oleh SINR downlink disebut Coverage by $\mathrm{C} /(\mathrm{I}+\mathrm{N})$ level $(\mathrm{DL})$

3) Perhitungan area yang ditutupi oleh SINR uplink disebut Coverage by $\mathrm{C} /(\mathrm{I}+\mathrm{N})$ level (UL) 
4) Perhitungan area yang ditutupi oleh throughput downlink disebut Coverage by throughput (DL)

5) Perhitungan area yang ditutupi oleh throughput uplink disebut Coverage by throughput (UL)

\section{METODE PENELITIAN}

Metode dalam penelitian ini menggunakan perhitungan dan simulasi dengan software Atoll untuk menentukan cakupan area hasil perencanaan sistem LTE frekuensi $1800 \mathrm{MHz}$ dengan model propagasi Cost-231 Hatta yang memanfaatkan Bale Banjar untuk menempatkan base station di wilayah kota Denpasar. Parameter antena yang digunakan adalah standarisasi LTE yang direkomendasikan 3GPP. Flowchart metode penelitian dapat dilihat pada Gambar 5.

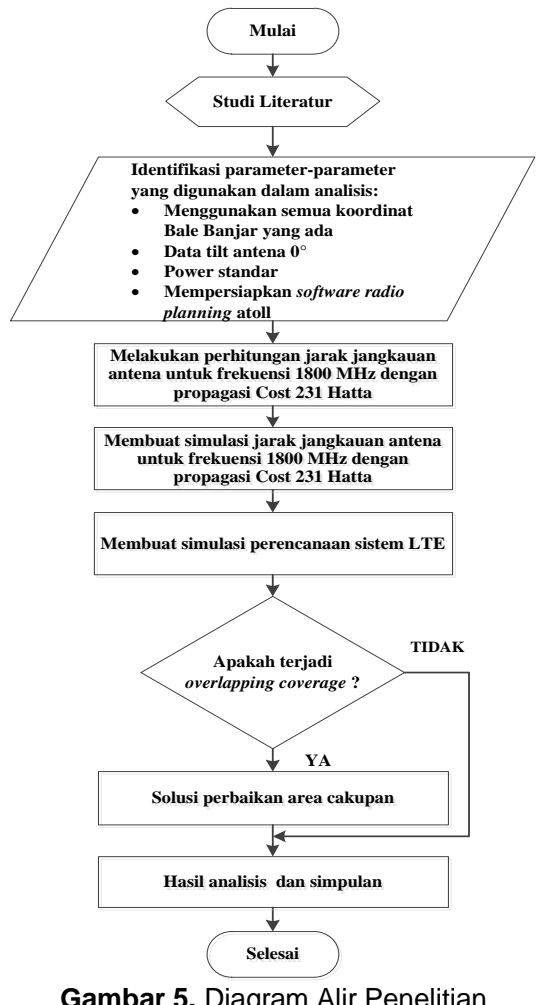

\section{HASIL DAN PEMBAHASAN}

\subsection{HASIL}

Hasil penelitian ini adalah jumlah optimal site Bale Banjar yang digunakan untuk mencakupi seluruh wilayah Kota Denpasar. Penelitian ini diawali dengan mengidentifikasi parameter yang digunakan dalam analisis meliputi data spesifikasi base station yang akan digunakan dalam simulasi perencanaan sistem LTE.
Kemudian dilanjutkan dengan menghitung nilai MAPL (Maximum Allowable Path Loss) yang akan digunakan dalam perhitungan model propagasi dan dibuat simulasi perhitungan jarak jangkau antena menggunakan software radio planning Atoll. Teknologi seluler yang digunakan adalah sistem LTE dengan frekuensi $1800 \mathrm{MHz}$. Wilayah yang akan dilakukan perencanaan sistem LTE adalah wilayah kota Denpasar yang memiliki permukaan geografis wilayah yang berbeda-beda, jika hanya menggunakan perhitungan, hasil yang didapatkan tidak optimal. Agar hasil menjadi optimal dibuatlah simulasi perencanaan sistem LTE yang dapat menggunakan peta digital dalam software Atoll. Dengan demikian kontur wilayah dapat terlihat pada hasil perencanaan.

\subsection{PEMBAHASAN \\ 4.2.1 Simulasi Perencanaan Sistem LTE}

Simulasi perencanaan sistem LTE dilakukan dengan menggunakan software radio planning atoll. Berdasarkan hasil perhitungan model propagasi dan simulasi jarak jangkauan antena yang digunakan sabagai acuan perencanaan sistem LTE. Tujuan dari simulasi perencanaan dengan memperhitungkan kontur wilayah adalah untuk mengetahui pengaruh kontur wilayah terhadap coverage area yang dihasilkan. Perencanaan yang dilakukan dengan cara menempatkan site berdasarkan koordinat Bale Banjar yang ada di wilayah kota Denpasar. Agar mendapatkan cakupan menyeluruh pada wilayah perencanaan maka dibuat rancangan sistem LTE 1800 $\mathrm{MHz}$ dengan model propagasi Cost-231 Hatta.

Hasil cakupan satu site yang diperoleh dari perhitungan dan simulasi jarak jangkauan antena model propagasi Cost-231 Hatta adalah 1,186 km.

Hasil simulasi perencanaan sistem LTE yang telah dilakukan dapat dilihat pada Gambar 6. 


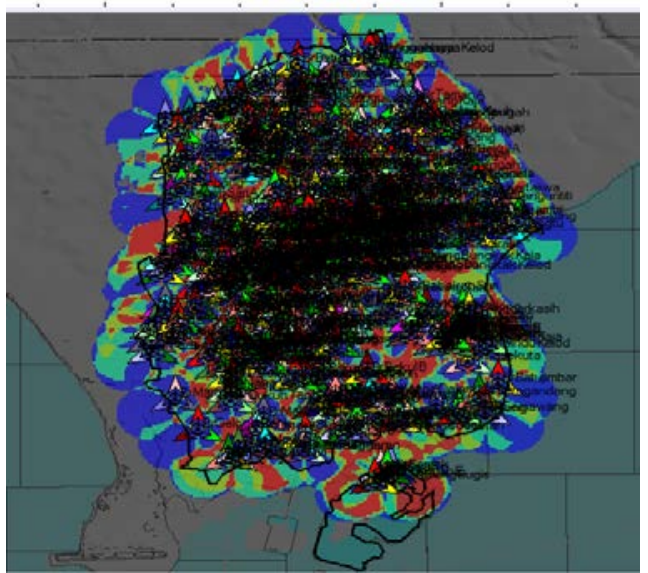

Gambar 6. Hasil perencanaan sistem LTE

Pada Gambar 6 terlihat bahwa kota Denpasar telah tercakupi oleh jaringan yang direncanakan menggunakan 385 Bale Banjar yang ada di kota Denpasar. Berdasarkan data statistik simulasi perencanaan jaringan diperoleh nilai mean sebesar 2,33. Hal ini berarti tiap daerah rata-rata dicakup 2 hingga 3 site. Dari data tersebut dapat diperoleh kesimpulan bahwa kemungkinan terjadi pingpong handover atau handover yang berulang-ulang yang menyebabkan terjadinya dropcall cukup besar karena pada tiap-tiap daerah dilayani 2 hingga 3 base station. Maka perlu dilakukan perbaikan area cakupan berdasarkan hasil perencanaan yang diperoleh.

\subsubsection{SOLUSI PERBAIKAN AREA CAKUPAN}

Penelitian ini menawarkan perbaikan area cakupan yang dilakukan dengan tiga cara yaitu, 1) melakukan seleksi site yang overlapping, 2) pengaturan tilt antena, pengaturan power yang dipancarkan, dan 3) penambahan site baru. Berdasarkan hasil prediksi overlapping zones pada hasil perencanaan sistem terdapat banyak area yang memiliki sel yang saling beririsan satu sama lain sehingga dilakukanperbaikan area cakupan

\subsubsection{Seleksi Site Overlapping dan Mengatur Arah Antena}

Solusi pertama yang dilakukan untuk perbaikan area cakupan adalah melakukan seleksi site atau mengurangi jumlah site. Pemilihan site berdasarkan pembagian kelurahan atau desa di wilayah kota Denpasar yaitu sebanyak 43 kelurahan atau desa sebagai acuan pertama dan ditambah dengan 11 pada beberapa area yang blankspot setelah dilakukan pengaturan arah antena, diperoleh 54 site yang telah dipilih dengan hasil cakupan area yang lebih baik dan dengan coverage yang cukup untuk seluruh wilayah kota Denpasar. Hasil perencanaan setelah dilakukan seleksi site dan pengaturan arah antena dapat dilihat pada Gambar 7.

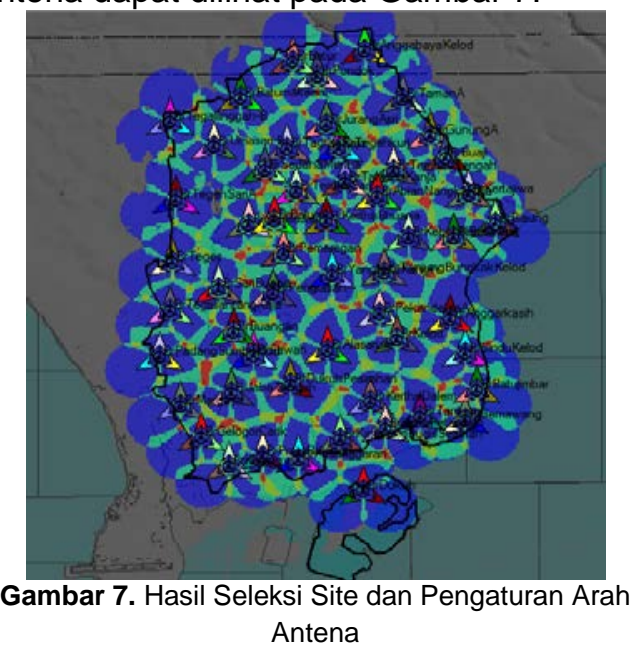

Pada Gambar 7 dapat dilihat hasil perbaikan area cakupan menunjukan area yang memiliki sel yang saling beririsan satu sama lain berkurang dari perencanaan awal yang menggunakan 385 site. Berdasarkan data hasil rekap statistik overlapping zonesdiperoleh mean sebesar 1,45 lebih kecil dibandingkan hasil perencanaan sebelumnya dengan mean sebesar 2,33. Hal ini berarti setelah melakukan perbaikan cakupan area, tiap daerah rata-rata dicakup 1 hingga 2 site. Kemungkinan terjadi pingpong handover atau handover yang berulang-ulang yang menyebabkan terjadinya dropcall kecil karena tiap-tiap daerah rata-rata dilayani oleh 1 hingga 2 base station, dan perencanaan overlapping zone baik untuk diimplementasikan. [7]

\subsubsection{Pengaturan Tilting Antena}

Permasalahan Blank Spot diatasi menggunakan hasil perbaikan seleksi site overlapping. Sebagai solusi area cakupan yang kedua yaitu pengaturan tilting antena. Sebagai acuan pengaturan tilt antena berdasarkan pada hasil coverage area pada simulasi perbaikan overlapping zones, tilt yang dilakukan adalah electrical tilting. Jarak jangkauan antena akan mengecil akibat sudut kemiringan yang besar pada antena, menyebabkan posisi antena semakin menunduk dengan perubahan sudut antena yang tidak konstan. Terjadi perubahan jarak yang tidak sama pada 
setiap satu derajat mulai dari sudut $1^{\circ}, 2^{\circ}$, $3^{\circ}$, hingga $10^{\circ}[1]$. Hasil pengaturan electrical tilting antenna dapat dilihat pada Gambar 8.

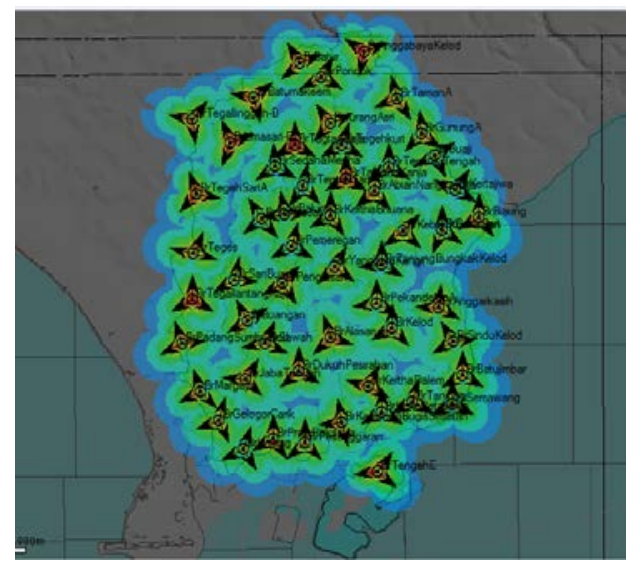

Gambar 8. Hasil Cakupan Pengaturan Electrical Tilt Antena

Pada Gambar 8 dapat dilihat hasil pengaturan electrical tilting, terlihat blank spot area pada hasil perbaikan sebelumnya sudah tercakupi setelah melakukan pengaturan electrical tilt antena. Sebanyak 40 site dari 54 site yang dilakukan pengaturan electrical tilt antena agar memperoleh hasil cakupan yang lebih baik pada wilayah perencanaan sistem LTE.

Untuk blank spot area pada daerah selatan kota Denpasar, tepatnya di wilayah Serangan tidak dapat tercakup melalui dua tahap solusi perbaikan cakupan area. Hal ini karena wilayah tersebut hanya terdapat beberapa Bale Banjar yang berposisi pada daerah cakupan yang sama sehingga cakupan untuk wilayah sekitarnya tidak mampu mencakup wilayah tersebut. Hal ini karena pada daerah blanskpot tersebut bukan wilayah permukiman, tidak ada terdapat Bale Banjar pada daerah tersebut. Permasalahan blank spot di area ini dapat dilakukan dengan solusi perbaikan cakupan area yang terakhir yaitu melakukan penambahan site baru agar wilayah Serangan tersebut dapat tercakupi.

\subsubsection{Penambahan Site Baru}

Solusi perbaikan cakupan area yang ketiga adalah penambahan site baru. Solusi ini dilakukan agar dapat mencakupi daerah blank spot berdasarkan permasalahan cakupan area yang diperoleh dari hasil perencanaan yang telah dilakukan. Solusi terakhir ini diharapkan dapat memperbaiki area blank spot pada wilayah Serangan yang tidak terdapat Bale Banjar. Pemilihan lokasi untuk penambahan site baru ini berposisi pada koordinat Longitude $115^{\circ} 13^{\prime} 40,31$ "E dan Latitude $8^{\circ} 44^{\prime} 13,4$ 'S, penempatan site baru ini memanfaatkan LPJU (Lampu Penerangan Jalan Umum) yang ada dikawasan Serangan. Selain pada menara rooftop, antena jaringan LTE di wilayah kota Denpasar juga memanfaatkan LPJU sebagai penempatan antena base station, pemanfaatan fasilitas publik ini juga mempermudah dalam aspek perijinan sehingga tidak perlu membuat perijinan untuk lokasi baru. Hasil prediksi cakupan area dan lokasi penempatan site barupada simulasi dapat dilihat pada Gambar 9, dan Gambar 10.

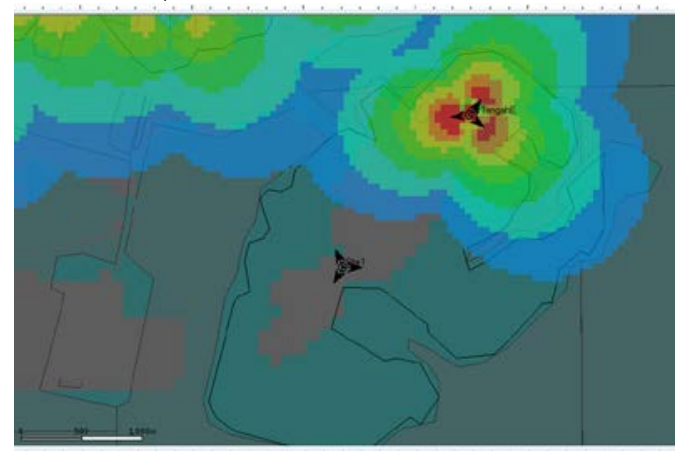

Gambar 9. Lokasi Penambahan Site Baru

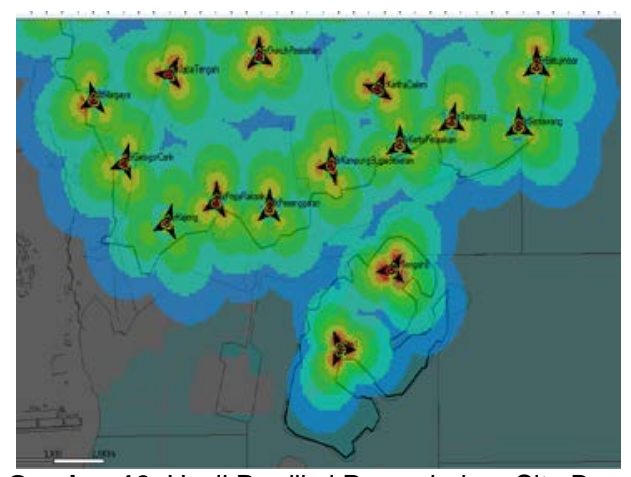

Gambar 10. Hasil Prediksi Penambahan Site Baru

Pada Gambar 8, 9, dan 10 dapat dilihat hasil penambahan 1 site baru pada daerah Serangan sudah mampu mencakup daerah tersebut. Namun masih ada sedikit blank spot pada sisi-sisi pesisir wilayah Serangan, walaupun sudah dilakukan upaya perbaikan cakupan area berupa pengaturan electrical tilt, power sebesar 43 $\mathrm{dBm}$ merupakan power maksimal yang digunakan. Upaya penambahan site baru ini sudah memberikan cakupan lebih baik di wilayah Serangan untuk mencakup wilayah tersebut yang masih terdapat beberapa akses jalan. Hal ini karena daerah Serangan tersebut memiliki kontur wilayah memanjang dan tidak merata, serta wilayah 
blank spot pada hasil perencanaan bukan merupakan wilayah permukiman melainkan pesisir teluk dan danau yang sifatnya tidak penting untuk mendapat cakupan jaringan seluler. Jadi penambahan site baru ini sudah memberikan hasil yang optimal untuk mencakup wilayah tersebut.

Hasil akhir perencanaan yang telah di ekspor ke google earth dapat dilihat pada Gambar 11.

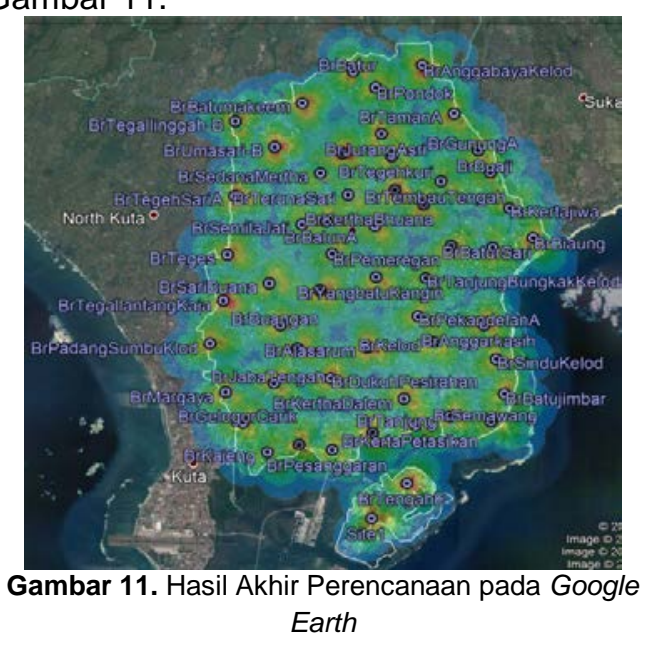

Pada Gambar 11 terlihat bahwa kota Denpasar telah tercakup oleh jaringan yang direncanakan. Dari 385 Bale Banjar yang ada di wilayah kota Denpasar hanya diperlukan 54 Bale Banjar yang diperlukan untuk mendapatkan cakupan menyeluruh pada kota Denpasar, dibutuhkan 55 site yang terdiri dari 54 site tiga sektor berdasarkan koordinat Bale Banjar dan penambahan 1 site di luar kawasan Bale Banjar dengan parameter yang telah dianalisis.

\section{Kesimpulan}

Dari pembahasan yang telah diuraikan sebelumnya, maka didapat jumlah site memanfaatkan Bale Banjar untuk perencanaan sistem LTE sebanyak 54 site belum dapat mencakup seluruh wilayah Kota Denpasar karena adanya blankspot area pada wilayah Serangan karena tidak terdapat Bale Banjar pada area tersebut.

Solusi permasalahan blankspot area di wilayah Serangan dilakukan dengan penambahan site baru dengan memanfaatkan lampu penerangan jalan sebagai lokasi penempatan site agar wilayah Serangan dapat tercakupi dengan sistem jaringan LTE $1800 \mathrm{MHz}$.
[1] Putra, T. G. A. S. 2015. Analisis Pengaruh Model Propagasi Dan Perubahan Tilt Antena Terhadap Coverage Area Sistem Long Term Evolution Menggunakan Software Atoll (tugas akhir). Denpasar : Universitas Udayana

[2] Dewi, K.L.K. 2014. Perencanaan Coverage Pada Sistem Long Term Evolution $700 \mathrm{Mhz}$ di Kota Denpasar (tugas akhir). Denpasar : Universitas Udayana

[3] Dewantoro. 2014. Menuju Broadband Wireless Access 4G, 5G. Edisi Bahasa Indonesia. Jakarta. Nulis Buku.

[4] Pinem, K. K. 2014. "Analisis Link Budget pada Pembangunan BTS Rooftop Cemara IV Sistem Telekomunikasi Seluler Berbasis GSM Studi Kasus PT. Telkomsel" (tugas akhir). Medan : Universitas Sumatera Utara.

[5] Kautsar, F.A. 2009. Optimasi Pelayanan Jaringan Berdasarkan Drive Test. (tugas akhir). Jakarta: Universitas Indonesia.

[6] Fauzi, M.R., Sukiswo. 2014.

Perencanaan Jaringan Lte (Long Term Evolution) Menggunakan Software Radio Planning (Atoll) (tugas akhir). Semarang : Universitas Diponegoro.

[7] Anastasia, Clara. 2016. Perencanaan Terrestrial Trunked Radio (Tetra) Digital pada Kereta Bandara Soekarno Hatta - Halim Perdana Kusuma. Jurnal Fakultas Teknik Elektro, Universitas Telkom

\section{Daftar Pustaka}

